\title{
ENTREVISTA
}

\section{OS MELHORES PROFESSORES DO MUNDO}

Quais são os melhores professores do mundo? Anualmente, a Fundação Varkey concede o prêmio de 1 milhão de dólares para quem é exemplo de proatividade e criatividade em prol do impacto social positivo da educação. Entre os 10 finalistas do Global Teacher Prize 2019 esteve a brasileira Débora Garofalo, que concede esta entrevista exclusiva para o Boletim Técnico do Senac.

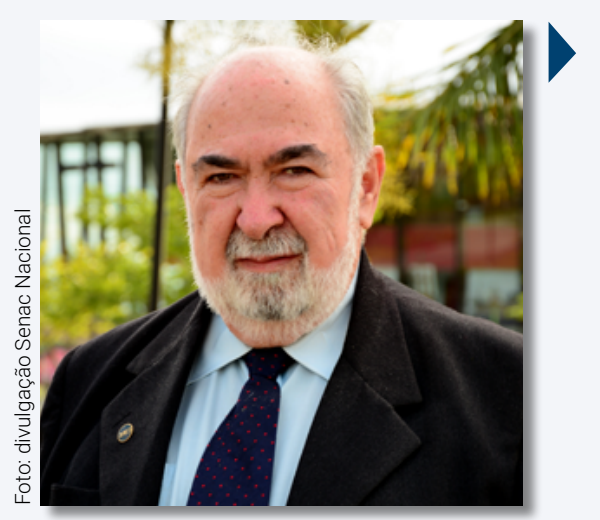

Francisco Aparecido Cordão

Especialista em Educação Profissional, Diretor da Peabiru Educacional e Titular da Cadeira 28 na Academia Paulista de Educação.

E-mail: facordao@uol.com.br

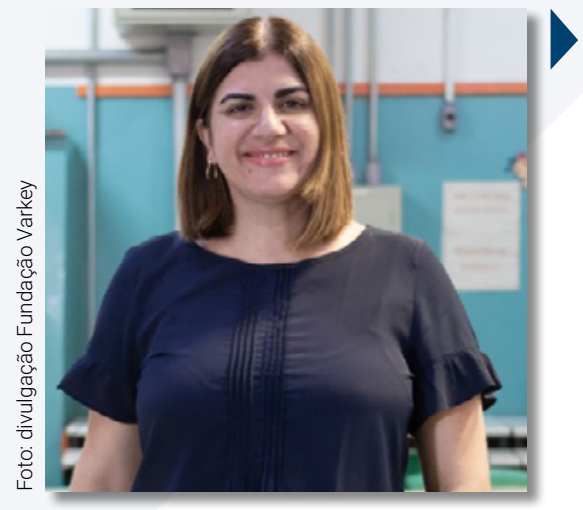

Débora Garofalo

Professora do ensino básico da rede pública de São Paulo e finalista do prêmio Global Teacher Prize 2019. E-mail: deboradenisedias@hotmail.com 
FAC- Primeiramente, gostaria que falasse um pouco sobre seu trabalho em uma escola pública na periferia de São Paulo: faixa etária dos alunos, disciplinas e projetos que promove e suas implicações sociais.

DG- O projeto Robótica Sucata foi desenvolvido e estruturado para transformar a vida de crianças e jovens da periferia de São Paulo e traz ao palco a construção de utensílios reciclados do lixo retirado das ruas da cidade como forma de mediar a construção de conhecimento de conteúdos curriculares, de eletrônica e de robótica.

A faixa etária dos alunos é de 6 a 14 anos. O projeto tem atuado diretamente na transformação da vida de 2.000 jovens e crianças da comunidade escolar da rede pública, que participam ou já participaram do projeto.

O trabalho é organizado de forma interdisciplinar, para mobilizar uma prática pedagógica e formativa que incentive a aprendizagem do aluno pela sua criatividade e inventividade, estimulando a experimentação de ideias e a exploração de pesquisas para propor soluções locais à comunidade. Uma dessas soluções que se destaca é a reciclagem feita pela coleta de lixo de São Paulo que dá origem à construção de robôs e materiais de eletrônica.

O projeto ainda propõe a construção de diferentes protótipos com placas programáveis, como Arduinos e Microbit. Dessa forma, o trabalho de Robótica com Sucata envolve diversas áreas do conhecimento, possibilitando uma aprendizagem mais ativa e atuante ao aluno. Mais que isso, o projeto tem ajudado a pensar a escola que não só produza conhecimento, mas também traga contribuições locais, como: a retirada de lixo das ruas de São Paulo, 1 tonelada de materiais recicláveis, transformando em protótipos com funcionalidades específicas, estimulando a responsabilidade social e o pensamento científico.

FAC- A proposta de trabalhar com a cultura maker ligada à robótica e ao meio ambiente levou você à classificação entre os 10 Melhores Professores do Mundo. Como foi a receptividade dos alunos ao aprendizado da cidadania por meio da qualificação para o trabalho?

DG- Quando comecei o trabalho com os alunos, eles não se sentiam capazes de aprender sobre a robótica, um duro golpe ouvir que seus alunos não se sentem capazes. À medida que eles foram se envolvendo com o trabalho, a percepção sobre o ensino foi mudando e a autoestima dos alunos, evoluindo.

Hoje em dia, vivemos a indústria 4.0, é essencial que a cultura maker, a linguagem de programação e a robótica estejam inseridas como currículo na escola, vivenciando na educação básica a resolução de problemas, o raciocínio lógico, a colaboração e a empatia, preparando nossos jovens para lidar com o trabalho. 
FAC- Na sua opinião, como o vencedor do prêmio de 2019, Professor Peter Tabichi, pode inspirar os professores brasileiros que atuam nas periferias das grandes cidades; no campo e nas regiões ribeirinhas; nas comunidades quilombolas e indígenas; bem como com populações itinerantes?

DG- O trabalho do professor Peter tem semelhanças com o nosso, por ter conseguido, mesmo sem recursos, que os alunos inovassem e vencessem a feira de ciências nacional do Quênia, demostrando que, muitas vezes, ter altos recursos tecnológicos não é garantia de efetivação da aprendizagem.

FAC- 0 que você traz de lição a partir dessa experiência da convivência com os 10 Melhores Professores do Mundo em Dubai?

DG- Durante sete dias, fiquei muito próxima aos professores finalistas (devido à agenda do evento) e descobri que tínhamos muito em comum: a vontade de transformar vidas, a indignação diante de situações como a falta de valorização docente, questões de pobreza, falta de políticas públicas bem como o estímulo ao uso das tecnologias como propulsoras da aprendizagem - mesmo onde os recursos são escassos, o uso de ferramentas digitais foi essencial para promover a diferença.

Não é preciso de altos recursos para ensinar e aprender tecnologia. Não é preciso ser um expert para construir e transformar a partir do zero. Trabalhar com tecnologia independe de credo, cor, raça e religião e todos podemos e devemos aprender uns com os outros. A educação é a única arma para mudar uma sociedade. 